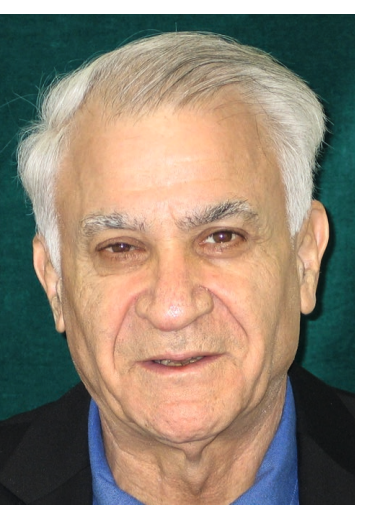

\section{Understanding Global Crises: An Emerging PARADIGM}

\author{
AsSAF RAZIN*
}

\section{Introduction}

Pre-2008 crisis economists failed to put the multitude of elements behind global crises into a coherent analytical framework. Major factors that underlay the global crisis were:

1. The destabilizing cumulative effects of financial deregulation, hedge funds, electronic trading, financial entrepreneurship, moral hazard, regulatory laxness, regulatory hazard (such as 'mark to market');

2. The Phillips curve-justified persistent monetary ease, subprime mortgages, derivatives and mortgage-backed securities;

3. The one-way-street speculation leading to riskshifting incentives, 'too-big-to-fail' financial intermediaries, hard asset bubbles (real estate, commodities, energy);

4. The structural deficits with fiscal hidden liabilities, special interest transfers, global imbalances; and more.

All of these unrecognized pressures simmered without any policy response - perhaps because economists had come to believe that policy makers had learned how to tame the financial beast - for decades after the Great Depression. With the advantage of hindsight, more than half a decade after the global crisis, both the strengths and weaknesses of the economic consensus that existed before the 2008 crisis can usefully be discerned and appraised, with an eye toward parsing the future directions of research.

The 2008 global financial crisis that erupted in the United States instantaneously swept across Europe.

Cornell University and Tel Aviv University.
Like the United States, the European Monetary Union (EMU) was ripe for a crash. It had its own realestate bubble (specifically in Ireland and Spain), had indulged in excessive deficit spending, was financially deregulated, and had rapidly expanded credit (partly through derivatives). A critical piece of the financial crisis and its perplexing aftermath is global imbalances, often called the global savings glut. This means that some nations (like China, for example) underconsume and over-export, while other nations, such as the United States, over-consume and over-import, devaluing the latter's currency and pressuring its Federal Reserve to keep interest rates too high for the purpose of stimulating recovery. Asia's liquidity glut flooded into the wide-open, lightly regulated American shadow banking system (including mortgage institutions) and inundated many smaller countries such as Iceland, Ireland, and Estonia sparking speculation and asset bubbles that soon burst with dramatic adverse effects on risk perceptions in the world's short-term interbank loanable funds market. Burst asset price bubbles reduced the worldwide lending ability of banks, a problem compounded by tightened loan requirements limiting the access of banks to emergency credit infusions. The international dimension coupling the East and West beyond the obvious trade linkages was not only important for its restrictive impact on monetary policy; it was also a key element in the larger global financial crisis.

The recent crisis had some similarities with the Great Depression. It appears that in both cases, the trigger was a credit crunch following a sudden burst of assetprice and credit bubbles. The recovery in world industrial production started much earlier in the Great Recession than in the Great Depression. Periods of depressed output were significantly shorter in the former than the latter, thanks to different policy reactions and improved financial and budget institutions. This does not amount to a claim that economists understand how to use fiscal policy and supplementary monetary instruments to recover optimally or prevent future reoccurrences, given the often - destabilizing expectations of the private sector due to conflicting incentives, finance fragility, and politically gridlocked governments. Rather, it means that complacency 
based on incomplete knowledge of how the system works is no longer tenable, and a reassessment of past output, employment, and finance stabilizing measures is called for.

\section{Pre-crisis conventional wisdom}

Pre-crisis conventional wisdom held that business cycle oscillations were primarily caused by productivity shocks that lasted until price- and wage-setters disentangled real from nominal effects, or monetary shocks, in view of staggered wage and price adjustments. These real and monetary shocks sometimes generated inflation or deflation, which was best addressed with monetary policy. Accordingly, central bankers were tasked with the mission of maintaining slow and stable inflation. Zero inflation and deflation were shunned, because they purportedly were incompatible with full capacity and full employment and well-managed monetary policy. Central bankers were supposed to be less concerned with real economic activity, many came to believe that full employment and 2 percent inflation could be sustained indefinitely by divine coincidence. The divine coincidence was said to be made all the better by the analytical discovery that real economic performance could be regulated, in theory, with only a single monetary instrument: the short-term interest rate. Evidently, arbitrage across time meant that central banks could control economy-wide temporal interest rates, short and long, and arbitrage across asset classes implied that the Federal Reserve ('the Fed') could similarly influence risk-adjusted rates for a diverse set of securities. Fiscal policy, which had 'ruled the roost', as it were, under the influence of crude Keynesianism from 1950 to 1980 , was relegated to a subsidiary role of macroeconomic stabilization in this manner. This view was reinforced by macroeconomic theorists' beliefs in the empirical validity of frictionfree Ricardian-equivalence arguments and scepticism about lags and political gridlocks, which makes discretionary fiscal policy as a stabilization tool practically irrelevant.

It is also true that the financial sector was also given little thought in macroeconomic theory, because financial sector prudential policy was perceived as regulatory only, affecting structural performance, but not business cycle performance, rather than as an aggregate demand management issue. The consensus view held that automatic stabilizers such as unemployment insurance should be retained in order to share private- ly uninsurable risks. Federal deposit insurance was preserved to deter bank runs, and commercial banks' credit and investments continued to be regulated to prevent moral hazard under the federal deposit insurance, but otherwise finance was lightly supervised, especially 'shadow banks', hedge funds, mortgages, and derivatives.

\section{Two camps}

Needless to say, most of the macroeconomic theorists now concede that the pre-crisis monetarist consensus was mistaken. Both recognise that with the Fed funds rate near the zero lower bound, the burden for stimulating recovery and short-term growth falls to nonconventional monetary policies, such as quantitative and credit easing. But, the agreement stops here. From this point on, the profession has split into two contending camps.

The 'Ricardian faction' contends that further overbudget spending with deficit to GDP ratios in many large nations such as the United States will drive up interest rates, crowd out private investment, and have a negative stimulatory impact. This could easily generate recession (depression) coupled with a bout of high inflation (deflation), due to excessive commercial bank liquidity. This is reminiscent of Friedrich Hayek warning that a surge of excessive liquidity can misdirect investments leading to a boom followed by a bust.

However, members of the other camp, concerned about the non-Ricardian conditions, such as credit frictions, market freezes, liquidity traps, and deflation, see matters vice versa. They insist that austerity policies and deflation are the danger under depressed markets (which via the Bernanke doctrine implies a Great Depression with rising real wages and excess savings). They deduce that avoidance of disaster hinges on temporarily raising public spending to fill in the gap of shrinking private spending, continued central bank credit easing, and quantitative easing. They are aware that this could have inflationary ramifications, which is helpful to lower the real interest rate, but brush the soon-to-arrive inflation peril aside by claiming that speculators will absorb most of the idle cash balances governments are prepared to print, because with zero interest rate, money and bonds are perfect substitutes. At the same time, inflationary expectations are to be replaced by deflationary expectations. Moreover, they contend that excess base money can be drained from 
the system, whenever banks decide to resume lending, but not fully, during a long period of de-leveraging by households and firms. And, as the icing on the cake, they proclaim that large multiplier effects during depression-like situations will not only raise employment, but also provide the wherewithal to repay the government debt. They also emphasize the longerterm implications of deep unemployment that create a segment of the labour force that may become unemployable.

Notwithstanding these disagreements, the bottom line, therefore, is that the pre-2008-crisis faith in just one monetary lever, ensuring stability and growth, happened to be only wishful thinking. The dynamics of macro-aggregates depends on heterogeneous expectations, information, and contractual and credit frictions of erstwhile utility seekers under incomplete information, in morally hazardous and incomplete financial markets, subject to sundry shocks. Policy management is correspondingly complex, particularly in the presence of de-leveraging and liquidity trap conditions; and still more challenging in imperfect regulatory regimes where low inflation is targeted to ensure full employment and rapid economic growth, susceptible to moral hazard, adverse selection, coordination failures - the unavoidable characteristics of any financial intermediation. That is, we should not lose sight of the financial sector as a central pillar of the macroeconomic model. Fiscal policy also needs serious rethinking.

\section{Financial crisis analytics}

\section{Historical comparison of crisis}

The following crises were briefly characterised in this chapter: (a) the credit implosion leading to a severe banking crisis in Japan; (b) the meltdown of foreign reserves triggered by foreign hot-money flight from the frothy economies of developing Asian nations with fixed exchange rate regimes; (c) the global financial crisis; and (d) the Eurozone crisis.

Let us recall that Japan was slashed by a speculative tornado in 1986-1991. It was localized, brief, and devastating, with allegedly paralytic consequences often described as the 'lost decades' (1986-2013; before Abeeconomics). The phenomenon was a selective price bubble, disconnected from low and decelerating GDP inflation all the way to deflation, as well as more vigorous but diminishing rates of aggregate economic growth converging asymptotically toward zero, or worse.

The Asian financial crisis that erupted in 1997 was triggered by a foreign capital flight, which induced liquidity and credit implosion. It began as a run on Asian banks by foreign short-term depositors and expanded into an assault on government foreign currency reserves, sending shock waves as far as the shores of Russia and of Argentina.

The global financial crisis triggered the deepest and longest recession since the Great Depression of the 1930s. The defining event of the 2008 global financial crisis was a 'hemorrhagic stroke': a paralytic implosion of the loanable funds markets. The post-September 2008 emergency was caused by the terrifying realization that major financial institutions, especially those connected with hedge funds, could not cover their current obligations either with asset sales or short-term bank credit because confidence in the value of their assets had been lost, and short-term lending suddenly ceased. People everywhere were panicked at the prospect of cascading financial bankruptcies, where the securities of failed companies contaminated the value of other assets, triggering margin calls, shuttered credit access, lost savings, bank runs, stock market crashes, liquidity crises, universal insolvency, economic collapse, and global ruination.

The global financial crisis, which erupted in the United States, instantaneously swept across Europe and triggered the Eurozone crisis. Like the United States, the European Monetary Union was ripe for a crash. As mentioned earlier, the EMU had its own real-estate bubble (specifically in Ireland and Spain), had indulged in excessive deficit spending, was financially deregulated, and had rapidly expanded credit (partly through derivatives). Policy responses and recovery patterns for key European Union members such as Germany, France (within the Eurozone), and Britain (outside the Eurozone) were similar. However, after the bubble burst and the crisis began unfolding, it became clear that the Eurozone plight differed from America's in one fundamental respect. There was no exact counterpart of Eurozone GIIPS (Greece, Ireland, Italy, Portugal and Spain) in the United States. Some American states had over-borrowed, but the sovereign debt crisis did not place individual states at deflationary risk or threaten the viability of the federal union. This does not apply to some members within the Eurozone. 


\section{Analytics of financial fragilities}

These fragilities and frictions are rooted in coordination failures, incentive problems, asymmetric information, risk-shifting behaviour, and excessive optimism among participants in collateralized debt markets. Each and every one of these forces is present in the global financial problems that occurred over the past decades.

Banks are known to finance long-term assets with short-term deposits. The advantage of this arrangement is that it enables banks to provide risk sharing to investors who might face early liquidity needs. However, this also exposes the bank to the risk of a bank run, whereby many creditors decide to withdraw their money early. The key problem is that of a coordination failure, which stands at the root of the fragility of banking systems: When more depositors withdraw their money from a bank, the bank is more likely to fail, and so other depositors have a stronger incentive to withdraw.

A key policy question is how to avoid the damages from coordination failures and runs in the financial system. While insurance has been effective, its implications for moral hazard have to be considered carefully, and so there is room for more research on the optimal deposit insurance policy. Using recent developments in economic theory, global-games models enable analysis of the benefit of insurance in mitigating runs against the cost in generating moral hazard, leading to characterisation of optimal insurance policy. In the above models of financial institution failures, the focus was on the behaviour of depositors or creditors of the banks. However, problems in the financial sector often arise from the other side of the balance sheet. The quality of loans provided by the banks is determined in equilibrium, and frictions exist that make banks cut on lending to protect themselves from bad outcomes.

While basic economic theory suggests that in equilibrium, prices adjust so that supply equals demand and no rationing arises, it shows that this will not occur in the credit market because of the endogeneity of the quality of the loan. The key frictions that stand behind rationing are moral hazard and adverse selection. A large body of recent literature studies the implications of such frictions for lending, especially the implications of moral hazard. If a borrower has the ability to divert resources at the expense of the creditor, then creditors will be reluctant to lend to borrowers. Hence, for credit to flow efficiently from the creditor to the borrower, it is crucial that the borrower maintains 'skin in the game'; that is, that he has enough at stake in the success of the project, and so does not have a strong incentive to divert resources. This creates a limit on credit, and it can be amplified when the economic conditions worsen, leading to a crisis.

\section{Currency crisis and balance of payment crises}

Currency crises occur when the country is trying to maintain a fixed-exchange-rate regime with capital mobility, but faces conflicting policy needs such as fiscal imbalances or a fragile financial sector that need to be resolved by independent monetary policy. An important aspect of financial crises is the involvement of the government and the potential collapse of arrangements it creates, such as an exchange rate regime. Many currency crises (e.g. the early 1970s breakdown of the Bretton Woods global system) originate from the desire of governments to maintain a fixed exchange rate regime that is inconsistent with other policy goals. This might lead to the sudden collapse of the regime. The literature on currency crises begins with the first-generation and second-generation models.

Such models are highly relevant to the current situation in the EMU. At the core of the theory of currency crises is the famous international finance tri-lemma, whereby a country can choose only two of three policy goals: free international capital flows, monetary autonomy, and the stability of the exchange rate. Countries in the Eurozone now realize that in their attempt to achieve the first and third goals, they have given up on the second goal, and so have limited their ability to absorb the shocks in economic activity and maintain their national debts, triggered by the global financial crisis. Coordination problems among investors and currency speculators aggravate this situation and may have an important effect on whether individual countries in Europe are forced to default and/or leave the monetary union.

The third-generation models of currency crises connect models of banking crises and credit frictions with traditional models of currency crises. Such models were motivated by the East Asian crises of the late 1990s, where financial institutions and exchange rate regimes collapsed together, demonstrating the linkages between governments and financial institutions that can expose the system to further fragility. 
An additional aspect to be mentioned in this context is international capital flows with information frictions that are prone to the so-called sudden-stop phenomenon, whereby capital inflows unexpectedly dry up. Economists tend to favour capital mobility across national borders as it allows capital to seek the highest rate of return, adjusted for risk. Unrestricted capital flows also offer several advantages. Firstly, international flows reduce risk through diversification of lending and investment. Secondly, the global integration of financial markets can contribute to the spread of best practices in corporate governance, accounting standards, and legal practices. Thirdly, the global mobility of capital limits the ability of governments to pursue bad policies. In an integrated world capital market, with perfect information, all forms of capital flows are indistinguishable. Information frictions are important elements needed in order to differentiate between equity tradable debt and loan flows, as well as between various types of equity flows. Foreign direct investment (FDI) has proved to be resilient during financial crises. For instance, in East Asian countries, such investment was remarkably stable during the global financial crises of 1997/98. By sharp contrast, other forms of private capital flows - portfolio equity and debt flows, and particularly short-term flows - were subject to large reversals during the same period. If domestic and foreign investors differ in their information sets regarding future stock market returns, there is an efficiency-based pecking order of capital flows among debt foreign investment, portfolio foreign investment, and direct foreign investment.

\section{The emerging macroeconomic paradigm}

From an analytical framework that features full capital-market arbitrage, smooth credit, Ricardianequivalence properties, representative agents, and efficient monetary management, to the framework with multiple agents, which incorporates debt frictions, liquidity traps, and relatively ineffective monetary management and provides a role for fiscal policy in aggregate demand management. The analytical framework based on the frictionless paradigm effectively captures the role of globalization forces and the reduction in inflation in the 1990s Great Moderation era. The multiple-agent, market-friction revised analytical framework captures some key features of the Great Recession that occurred in the aftermath of the 2008 global financial crisis. It provides insights into the macroeconomic effects of debt overhangs on econom- ic activity and inflation, when the monetary policy rate reaches its lower bound.

\section{Conclusion}

Historical patterns of booms and busts typically exhibit frequent, small recessions interrupted by rare, but deep and long recessions. Traditional macroeconomic models, often used by central banks and many other policy-making institutions, are not capable of delivering crisis features in history: frequent small recessions are punctuated by rare depressions. A major challenge for macroeconomic research effort is to come to grips with the modeling failure and to offer empirically testable dynamic macro-models, which can combine interactions among the monetary, financial, and real sectors, consistent with the empirical regularities of business cycles. 